\title{
Slavery and spatial dialectics on Cuban coffee plantations
}

\author{
Theresa A. Singleton
}

\begin{abstract}
Slaveholders manipulated the spatial organization of plantations to their advantage in an effort to control the actions of enslaved workers. Slave workers, on the hand, always found ways to resist planter hegemony. Cuban slaveholders, not only employed surveillance measures comparable to those found elsewhere in the Americas, but they also housed enslaved people in prison-like quarters. Using both archaeological data and written sources, this essay examines plantation slavery in Cuba by analyzing the dialectal relationship between slaveowners' control of plantation space and enslaved laborers' resistance of that control.
\end{abstract}

\section{Keywords}

Slavery; Cuba; coffee plantations; archaeology; spatial organization.

\section{Introduction}

Cuba imported more than one million enslaved Africans from its beginning as a Spanish colony in 1511 to the abolition of slavery in 1886 . Of that number, over 780,000 enslaved Africans came to the island between 1790 and 1867, making it the greatest slave-importing colony of Spanish America and the center of the nineteenth-century transatlantic slave trade to the Caribbean (Bergad et al. 1995: 38). Slave importation of this magnitude transformed the island's economy from one of diverse activities in which no single activity defined the slave experience to a plantation economy based upon racial slavery.

As in other Caribbean islands, sugar mono-culture fueled Cuba's plantation economy, and, in 1840, Cuba became the world's leading producer of sugar (Paquette 1988: 29). Although sugar set Cuba's plantation economy in motion and determined its overall direction, coffee production played an equally significant role in shaping plantation slavery in Cuba during the first half of the nineteenth century (González Fernández 1991: 161). Even when Cuba was the leading producer of sugar, the number of coffee plantations outnumbered sugar plantations.

One of the most striking features of the Cuban plantation is what historian Moreno World Archaeology Vol. 33(1): 98-114 The Archaeology of Slavery 
Fraginals referred to as 'its jail-like structure' (1977: 189). This characterization aptly describes many slave-management practices adopted in Cuba, particularly those implemented to contain slave activities. One such practice, discernible in extant ruins of plantation buildings, was the housing of enslaved people in prison-like quarters. These quarters were often locked at night, and carefully watched by guards. Such surveillance measures seem extreme when compared with those of slave societies in Anglophone America, and therefore raises several questions: Why did plantation slavery in Cuba develop this jail-like character? Were these surveillance measures effective? How did enslaved people respond to this situation? This paper examines these questions by analyzing written sources, ruins of extant plantation buildings and preliminary archaeological data recovered from the slave quarters of a former Cuban coffee plantation.

\section{Plantation slavery and Cuba's coffee economy}

The early Spanish settlers brought enslaved Africans with them to Cuba, but the slave population remained one of the lowest in the Caribbean until the second half of the eighteenth century. Cuba was slow to develop a slave society like those of the English and French islands for several reasons: first, the asiento system which granted contracts for slave trading restricted the number of enslaved persons that could enter specific regions of the Spanish empire; second, the colonial settlement pattern of sixteenth- and seventeenth-century Cuba was designed for a sparsely populated cattle economy; third, the absence of a legal mechanism for private land ownership and the Spanish Crown's prohibitions on clearing forest lands hampered the development of agriculture (Bergad 1990: 22-5).

The eventual removal of these obstacles combined with the void in sugar and coffee production resulting from the demise of slavery in Saint Domingue (Haiti) ushered in favorable conditions for a plantation economy in Cuba. A planter class emerged from the Cuban-born élite and immigrants from other Caribbean Islands, North America and Europe. Together they produced a plantation society that historian Robert Paquette described as the 'best and worst of times' (1988: 35). These best of times for the Cuban planters resulted in the displacement of small-holding whites and the brutal use of African labor.

Cuba's coffee economy largely developed from the efforts of transplanted French exiles escaping from the Haitian Revolution, 1791-1802 (Pérez de la Riva 1944: 27-8; González Fernández 1991: 165). Experimentation with coffee cultivation, however, presumably occurred as early as 1748 (Gordon y Acosta 1896: 9). Coffee was produced primarily in the hilly and mountainous regions of both eastern and western Cuba, but the prosperity of the early nineteenth-century coffee economy was concentrated in western Cuba in the provinces of Havana, Matanzas and Piñar del Rio. By 1830, investments in coffee production in western Cuba were equal to those in sugar, and the number of enslaved workers employed on cafetales, coffee plantations, was often equal to that in the ingenios, sugar plantations (Bergad et al. 1995:29). Thus, coffee production was an important component of the development of the plantation slavery of Cuba in the first half of the nineteenth century. 
Coffee was always a secondary crop to sugar throughout the Caribbean, but it had distinct advantages over sugar. Its land requirements were small, and large initial investments in machinery or buildings were unnecessary. For these reasons, coffee attracted planters of diverse economic and social scales whereas sugar was generally restricted to the wealthy (Trouillot 1993: 131). Coffee, however, also had its drawbacks: depending on the variety of coffee it took four to seven years for the plants to mature (Trouillot 1993: 135). Because of the lag time between the initial investment in land and labor and the generation of income, coffee was also economically more complex and the trade tended to be more erratic than that in sugar (Bergad 1990: 57).

Cuba's coffee boom was short-lived, and several factors brought the demise of coffee production in western Cuba: in the 1830 s, Brazilian coffee became a major competitor of Cuban coffee; prices in the world coffee market dropped to about one-half of previous prices; '[t]ariff wars between Spain and the United States' (Pérez de la Riva 1944: 72) caused Cuba to lose the United States as an important market for its coffee. The United States raised its tariff on Cuban coffee in retaliation for Spain's high tariff on flour entering Cuba from the United States. Hurricanes in 1844 and 1846 destroyed numerous coffee plantations. In the years from 1854 to 1859 , planters abandoned their coffee plantations, converting some into sugar plantations (Pérez de la Riva 1942: 704). Several former coffee plantations inspected for this research project were never re-occupied; therefore, these sites offer archaeologists an opportunity to study slavery and plantation life from wellpreserved contexts.

\section{Cafetal del Padre and slavery on Cuban coffee plantations}

The primary coffee plantation discussed herein is known today as cafetal del Padre. It is located in Havana province approximately 75 kilometers south-east of the city of Havana within the Alturas de Bejucal-Madruga-Limonar, a natural sub-region of western Cuba, consisting of hills, plateaux and low-lying mountain ranges (Nuñez Jiménez 1959:109-14). In the nineteenth century this was an important region for both coffee and sugar plantations. Coffee was cultivated on the foothills of the mountains and sugar in the valleys. This hilly terrain is apparent in the immediate vicinity of the cafetal where the elevation ranges from 150 to 164 meters above sea level (see Fig. 1).

At this preliminary stage of research, it is unclear who first established a coffee plantation at the site El Padre. Local tradition suggests that French immigrants began the coffee plantation, farmed it briefly and later abandoned it (Carlos Suárez Sardiña 2000, pers. comm.). While this scenario awaits confirmation from written sources, it accurately portrays the experiences of many French planters, particularly in Western Cuba, whose coffee plantations were confiscated or destroyed. Due to the Napoleonic invasion of Spain from 1808 to 1812, French immigrants were expelled from Cuba and other Spanish colonies (Bergad et al. 1995: 95-6; Pérez de la Riva 1944:33-5). If not founded by French planters, the cafetal exhibits French influences in the H-shaped, floor plan of the casa vivienda (the slaveholder's house). It is identical to the 'typical plan of a French house' illustrated in a study of Cuban vernacular architecture (Pérez de la Riva 1952: 372).

During the boom years of Cuban coffee production between the 1820s and the 1840s, 


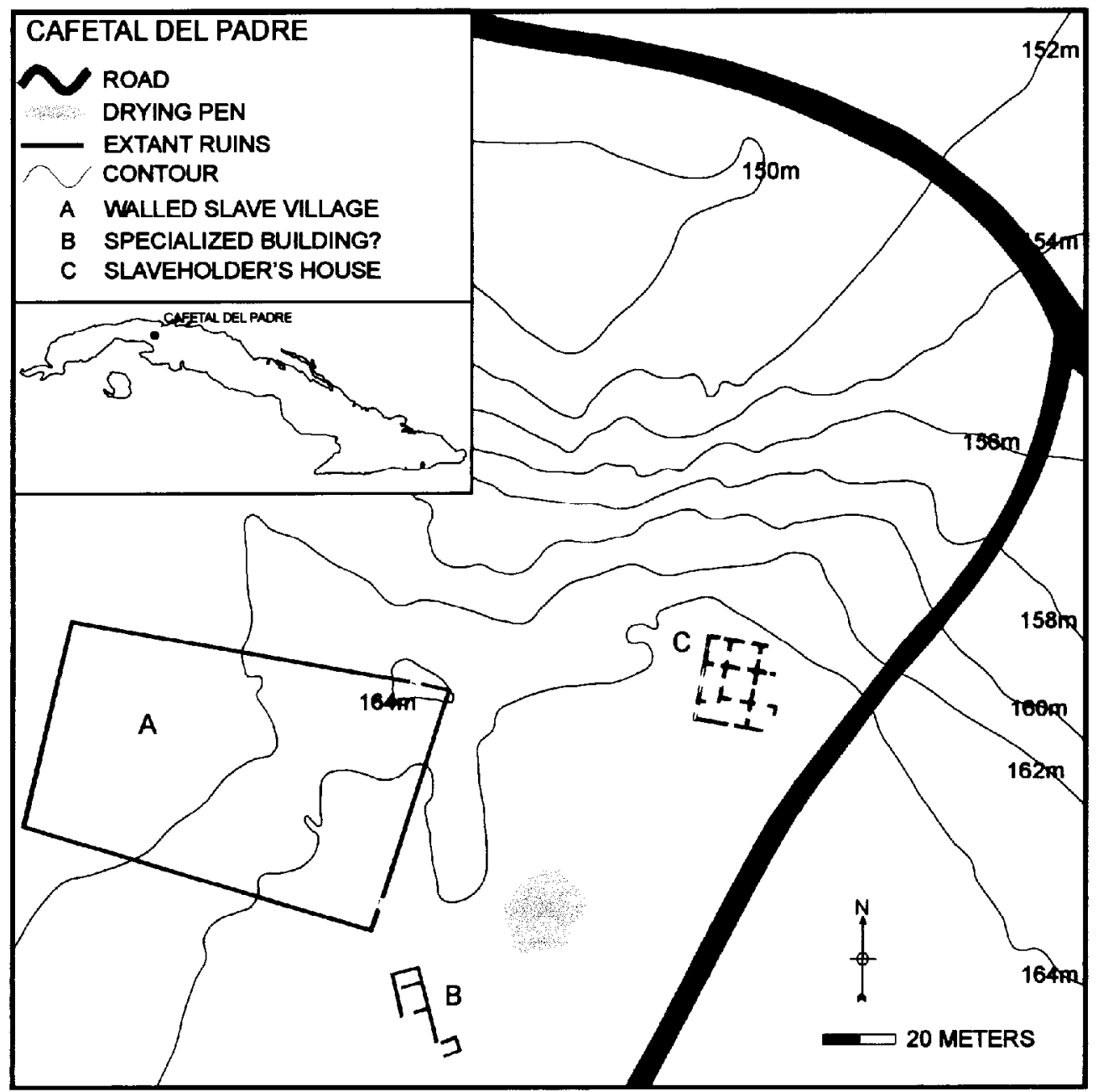

Figure 1 Composite site map of El Padre Coffee Plantation.

the O'Farrill family owned and operated the cafetal, known at that time as Santa Ana de Viajaca. The O'Farrills were one of the most distinguished and powerful families in nineteenth-century Cuba (Paquette 1988: 45). Richard O'Farrill, the Irish progenitor of the family, was born on the island of Montserrat and came to Cuba in the early eighteenth century (Franco Ferrán 1986: 7). He was granted an asiento on slave imports, and his profits derived from the slave trade laid the foundation for his descendants' fortune (Bergad 1990: 14). While it is unclear which O'Farrill first acquired cafetal Santa Ana de Viajaca, it became the property of Ignacio O'Farrill, a Catholic priest. Ignacio was the grandson of Robert O'Farrill. At some later time (possibly in the 1900s), the cafetal become known simply as 'El Padre', the father, presumably because it was once owned by a priest. In addition to the cafetal, Ignacio O'Farrill owned two sugar plantations: San Juan de Nepomuceno, close to the cafetal, and La Concordia, located in Tapaste, a nearby 
district in Havana province, and two stock-raising farms. Ignacio O'Farrill died in 1838, and his estate was divided equally between his heirs and his creditors (ANC, EMRH, 1834).

The cafetal began declining before Ignacio O'Farrill's death in 1838, and thereafter continued on a downward path. Interest accumulated on the unpaid taxes. Several court judgements were filed concerning the payment of the interest and for adjustments to the division and liquidation of properties. The final blow to the cafetal came when the hurricane of 1844 'destroyed all the coffee works' (ANC, AC, 1849-53). Coffee cultivation was never restored.

At the archaeological site of El Padre, the most imposing feature is a masonry wall $3.35 \mathrm{~m}$ high that encloses the slave village (Fig. 1). The wall, as well as the two other extant structures, the slaveholder's house and a specialized building of unknown function, were constructed of mampostería, a construction material consisting of stone, rubble and limebased mortar. The stone is often covered with a stucco-like solution made from a combination of lime, water, sand and other materials (Rebelledo 1910: 108-10). The exterior side of the wall is covered with the stucco-like substance, while the interior side of the wall is not.

Test excavations within the area enclosed by the wall yielded three distinct areas of post-holes forming what appears to be a row of structures. The vast majority of the artifacts recovered from in and around the structures date between 1800 and 1860, and therefore correspond with the period when the site was functioning as a cafetal. Only in one of three areas has it been possible to estimate the overall size of the building, which measures $5 \mathrm{~m} \times 7 \mathrm{~m}$. A series of posts approximately in the center of this rectangular space suggests that an interior wall divided the structure into two rooms. It was possibly a structure with two elements that housed two separate groups of people. The posts used in the construction were of varying sizes, but all were put in place either by cutting through or driving the posts through the limestone strata, a geological formation found throughout the Caribbean. These structures were presumably slave dwellings, known as bohios. The term bohio appears to be derived from a Taino Indian word that generally identifies a house built of a timber frame, walled with cane or clay, roofed with thatch, and with either an earthen floor or a raised wooden plank floor (Jopling 1988: 5-6). On Cuban plantations, bohio referred to a wide variety of slave housing, but the term was most often used to describe detached slave dwellings (cabins or huts) that housed enslaved people in household units in contrast to barracones - masonry structures in which the living areas of men and women were separated into prison-like cells (for a discussion on the distinction between the two types of housing, see Ortiz 1989[1916]: 199-202).

While the idea of enclosing slave houses behind a wall - higher than the average ceiling height of a modern American house - appears an extreme example of a slaveholder's control over the living spaces of the enslaved, it may have been less severe than the barracón. By far, the most notorious slave quarter identified as 'prison-like' by scholars of Cuban slavery was the barracón de patio (Bergrad 1990: 235; Moreno Fraginals 1978, 2: 74; Pérez de la Riva 1952: 387; Pérez de la Riva, J. 1975:29-42; Scott 1985: 17-19). This was a large, rectangular-shaped building usually constructed of mampostería that surrounded a patio, an open yard-like area located in the center. Some barracones were quite large and housed several hundred enslaved workers. Planters began to build these 
barracones in the 1840s to curb slave rebellions and runaways. None of the studies on Cuban slave housing, however, discuss the practice of enclosing slave quarters within a prison-like wall. Consequently, one research objective of the El Padre project is to determine the extent to which the wall represents the action of one or a few, individual slaveholders or is a more widespread slave-management practice.

At present, solutions to this problem are tentative. Despite the fact that scholars of Cuban slavery have not discussed wall enclosures surrounding slave villages, nineteenthcentury written and visual sources on Cuban slavery suggest enclosing a slave village within a wall was a known practice. The most direct reference comes from a list of regulations the governor of Matanzas province issued after a slave rebellion in that province. This little-known rebellion resulted in the deaths of fifteen whites and the burning and looting of twenty-four farms (Bergad 1990: 239; Barcia Paz 1999, pers. comm.). One of the security measures required of all farms with bohios was 'to build fencing or a palisade around the houses between 4 or 5 varas [a Spanish measurement about $.85 \mathrm{~m}$ ] high with a locked gateway for security' (ANC GSC 1825: 4, my translation). The required height of the fencing between $3.40 \mathrm{~m}$ and $4.25 \mathrm{~m}$ is consistent with the wall height of $3.35 \mathrm{~m}$ at $\mathrm{El}$ Padre. Although El Padre is not located in Matanzas province today, it was part of the westernmost districts of Matanzas Province for most of the nineteenth century (ANC Protocolo de Salinas 1829: 1671; ANC Gobierno General 1878). Therefore, construction of the wall may have been a direct response to the Governor's regulations.

Another example of slave houses enclosed within a masonry wall is evident in the ruins of Angerona. Located today near the western end of Havana province (Fig. 2), Angerona was one of the largest Cuban cafetales, reputed to have had 450 enslaved workers (Abbot 1829: 140). After the decline in coffee, it was converted into a sugar plantation. A published lithograph of Angerona when it was a sugar plantation depicts detached slave houses behind a wall, though the wall does not appear to be as tall as the wall at El Padre (Méndez 1952: 8). Today, the ruins at Angerona suggest the slave village was surrounded by a wall made of mampostería with an iron gate entry (Plate 1). The Reverend Abiel Abbot visited Angerona in 1828 when it was still a coffee plantation and noted: 'the negro huts enclose a large square, which is entered by an iron gate. When the plantation becomes a populous as the proprietor hopes it will, this square will be a little negro city' (1829:144). Although it is not clear to what kind of walls or fences the gate was connected, the description suggests that a wall enclosure with a gated entrance to the slave village existed even when Angerona was a coffee plantation.

A third, and perhaps the most telling, reference to enclosing a slave village within a wall or palisade is found in a collection of essays written on the state of Cuban agriculture and industries by Álvaro Reynoso in 1861. In his discussion on slave housing, Reynoso urged slaveholders to return to the old system of individual bohios, but said that this housing needed to be improved so that it was in good condition. He felt that the barracón system was the worst situation for housing enslaved people because it was inefficient and still could not protect slaveholders from those enslaved persons who were inclined to plot against slaveholders (1861:328). In closing, he stated 'one could fence in the entire [slave] village, for the best security, with a large wall, although we are convinced that such a precaution is not necessary' (1861:330, my translation). Reynoso's statement implies that building palisades around slave villages was at least considered, if not experimented with 


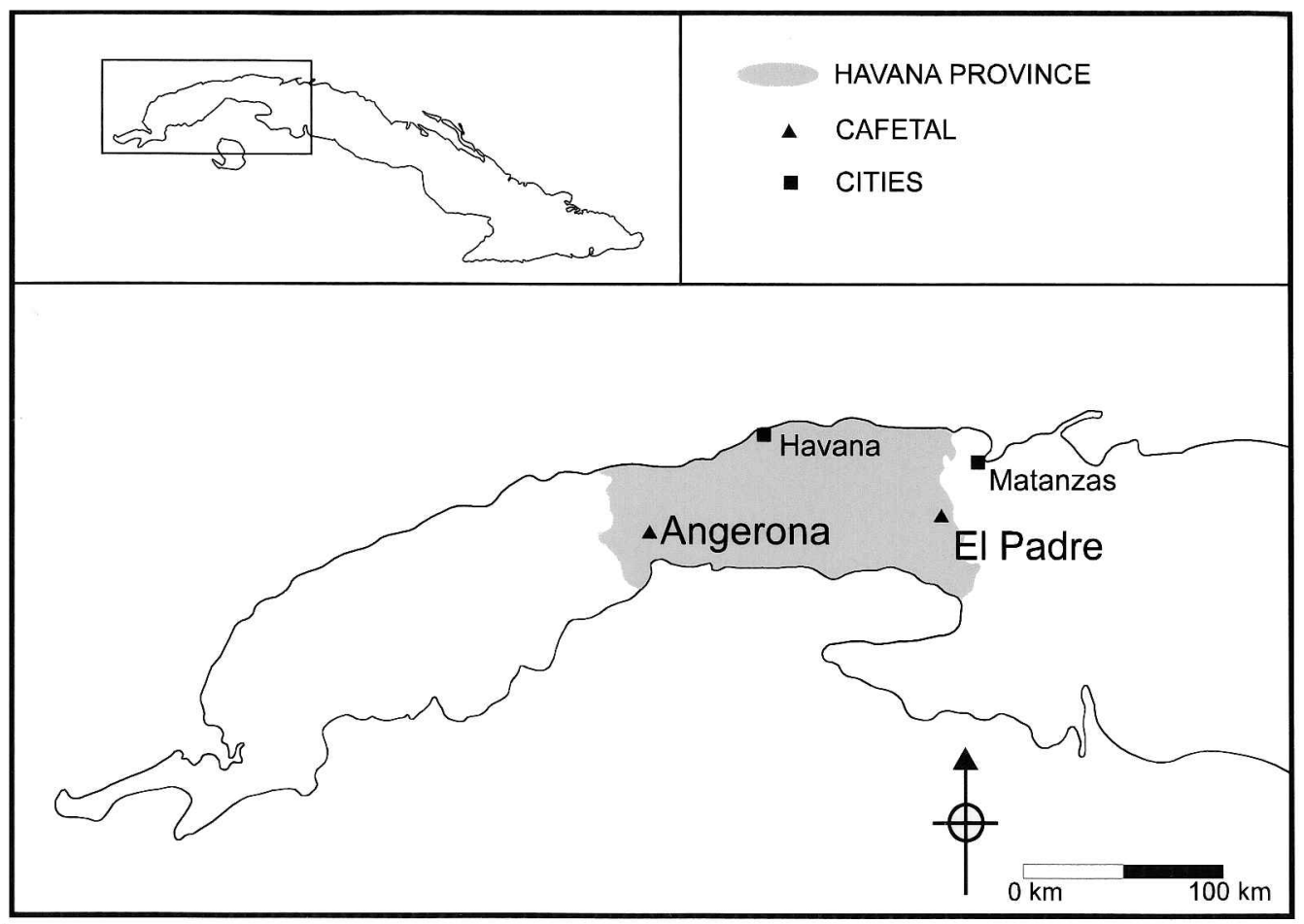

Figure 2 Location of Angerona and El Padre within Havana Province.

in Cuba. Moreover, the extant ruins at both El Padre and Angerona demonstrate that this practice did, indeed, occur.

The previously described written sources indicate that wall enclosures were built to contain slave activities. Similarly, stone-wall enclosures were used to keep enslaved people in during the Roman period and dependent serfs in during the medieval period. In both situations, the enclosure wall also served as a material manifestation for recognizing the intention of slave flight. When enslaved people were found outside the wall at inappropriate times, the wall prevented any ambiguity concerning slaves' actions (Samson 1992: 33). At the same time, wall enclosures also prevented the entry of strangers. The remainder of this essay examines the circumstances peculiar to Cuba that led to the prison-like surveillance of slave quarters and how enslaved people responded to it.

\section{Spatial dialectics on Cuban plantations}

Spatial dialectics, a concept attributed to Henri Lefebvre (1991), refers to various levels of space: physical, mental and cultural aspects of spatial arrangements that can be analyzed one by one but ultimately work together in a three-part dialectic (Shields 1999: 160-1). The concept is used here to begin an analysis of the dialectical relationship between slaveholders' control of space and enslaved people's resistance to that control as 


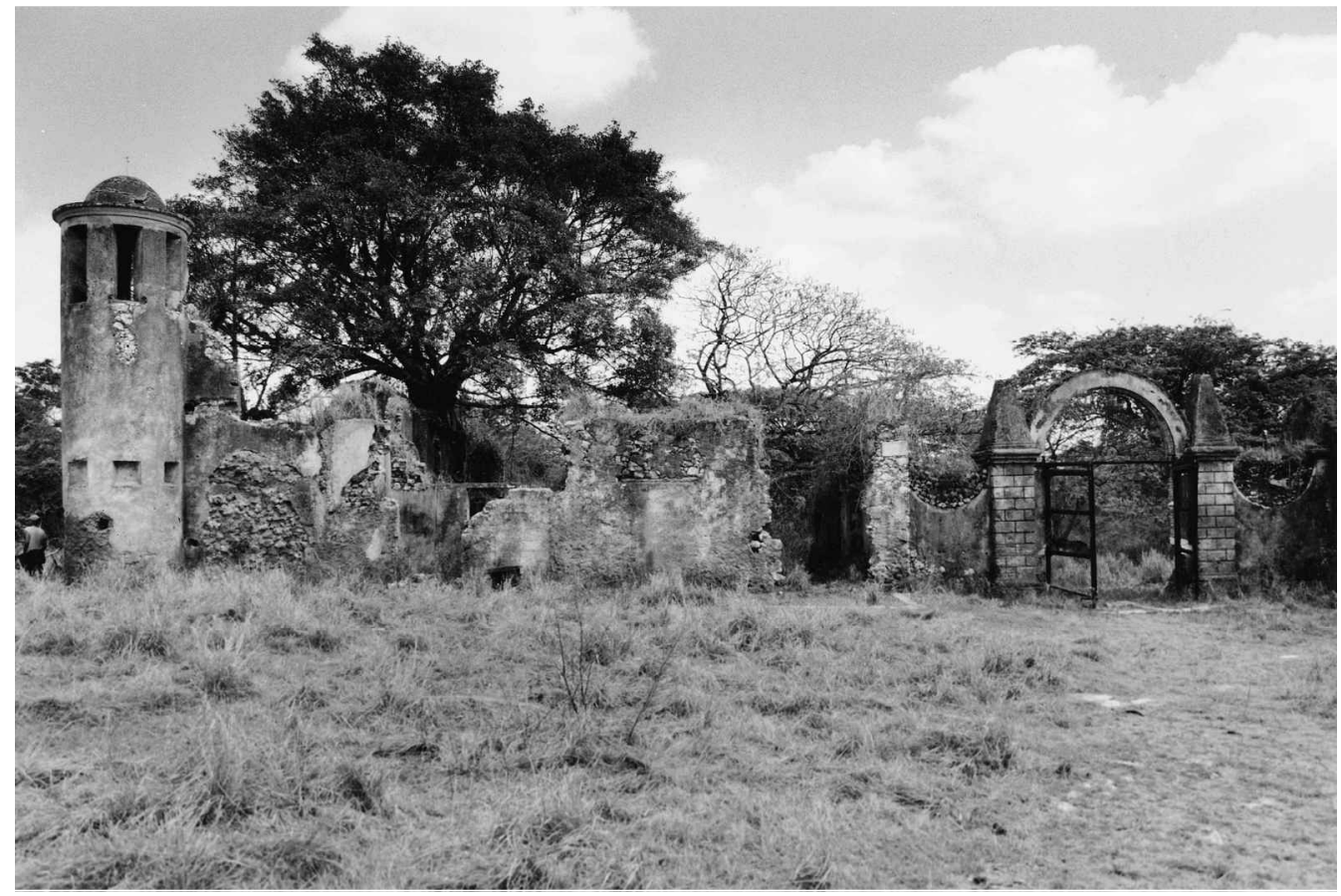

Plate 1 Ruins of wall enclosure of slave village at Angerona. Note: bell tower to left and iron gate entrance to the right.

seen in everyday life on Cuban plantations. Slaveholders everywhere manipulated the spatial organization of plantations in order to control enslaved people. Numerous archaeological, architectural and landscape studies have shown both direct and subtle ways planters attempted to control plantation landscapes (for a list of sources, see Singleton and Bograd 1995: 18-20). Nearly every aspect of plantation space from the location and arrangement of slave quarters (e.g. Armstrong 1990a; Epperson 1990,1999, 2000) to the details of slave-house construction (e.g. McKee 1992) resulted from conscious decision making on the part of planters to maximize profits, exercise surveillance and reinforce the subordinate status of enslaved people.

James Delle's study (1998) of coffee plantations in Jamaica is the most comprehensive analysis of spatial arrangements undertaken by an archaeologist in a plantation context. Using Foucault's (1979) analysis of panopticism, Delle demonstrates how the placement of the overseer's house served as a central point in surveillance in much the same way a guard tower does. Without leaving the house and veranda, the overseer could monitor the slave village uphill, watch enslaved workers walk from their house to their work and observe the coffee works and barbecues (coffee-drying pens) downhill (Delle 1998: 159).

According to Foucault, the panoptic mechanism arranges space in such way that surveillance is constant and takes place in full visibility. The panopticon reverses the principles of a dungeon, which are intended to enclose, hide or deprive light. The panopticon encloses but eliminates the need to hide or deprive light (Foucault 1979: 200). Given this 
definition, the wall enclosures at Angerona and El Padre appear antithetical to panoptic surveillance. Yet, some variation of panoptic or other form of surveillance would have been necessary to observe enslaved people within the village, at the coffee works and elsewhere on the plantation. The panopticon was rarely used in its pure form, but variations on it proliferated, and it became an important technology found in numerous, disparate realms of capitalist society (Epperson 2000: 59).

Wall enclosures in combination with panoptic surveillance were established at the nineteenth-century factory and town of Harpers Ferry, West Virginia. Brick walls were built to reorganize the space, restrict movements of factory workers and control entry to the factory yard. Monitoring activities took place from a central location, presumably from the superintendent's quarters located on one of the highest points in Harper's Ferry and with a commanding view of the factory grounds (Shackel 1996: 74-8). The walled slave villages at Angerona and El Padre may have operated in a similar vein. The bell tower pictured in Plate 2 possibly served as a panoptic surveillance device at Angerona. Panoptic surveillance is less obvious at El Padre, but may have taken place from the roof or a second level of the slaveholder's house. An imprint of a stairway that once ascended to an entrance above the ceiling level of the first floor is visible on the exterior south wall of the slaveholder's house (Plate 2). Cuban, French-styled great houses occasionally had a second floor, but the stairs were located inside the house, often in the living room placed within the center of the H-shaped floor plan (Pérez de la Riva 1952:372). Whether or not there was a second floor to the slaveholder's house at El Padre, a stairway existed at one time that ascended above the first floor, perhaps to the roof. That the roof could have served as a point of surveillance gains added support from the preliminary observations of architectural historian Miguel Herrera, who noted structural indications of balaustrada, a balustrade at the roof level of the house along the exterior north wall in 1999 (pers. comm. 2001). A rooftop terrace, known as an azotea, is an architectural feature often seen today on colonial period buildings in the city of Havana (Weiss 1989: 317, fig. 181). From such a rooftop terrace or similar construction, it would have been possible to observe activities taking place within the slave village as well as other locations on the plantation.

In addition to containing activities, wall enclosures were also designed to make entrance a hindrance (Samson 1992: 29). Cuban slaveholders desired to keep away from enslaved people anyone who would disrupt the work routine or the established social order. Maroons, slave runaways, could be particularly troubling for slaveholders because they would liberate enslaved people, take plantation supplies and destroy property. Wellorganized maroon communities lived in the mountain ranges surrounding coffee plantations in the Sierra de los Organos in the province of Piñar de Rio (Paquette 1988: 73-5) and Sierra del Grillo in Havana province (La Rosa Corzo and Pérez Padrón 1994). Beginning in late 1837 and continuing throughout 1838, maroon groups attacked several coffee plantations (La Rosa Corzo and Pérez Padrón 1994: 104-7; Bernard Bosch et al. 1985: 66). A cafetal named Santa Ana belonging to the O'Farrills was included among these plantations (La Rosa and Pérez Padrón 1994: 103); presumably this was Santa Ana de Viajaca, the site of El Padre.

Planters also desired to keep slave raiders away from their enslaved laborers. Slave raiding was a problem, particularly during periods of labor shortages. The great cholera epidemic of 1831-3 wiped out thousands of Africans in Cuba, and it occurred at a time 


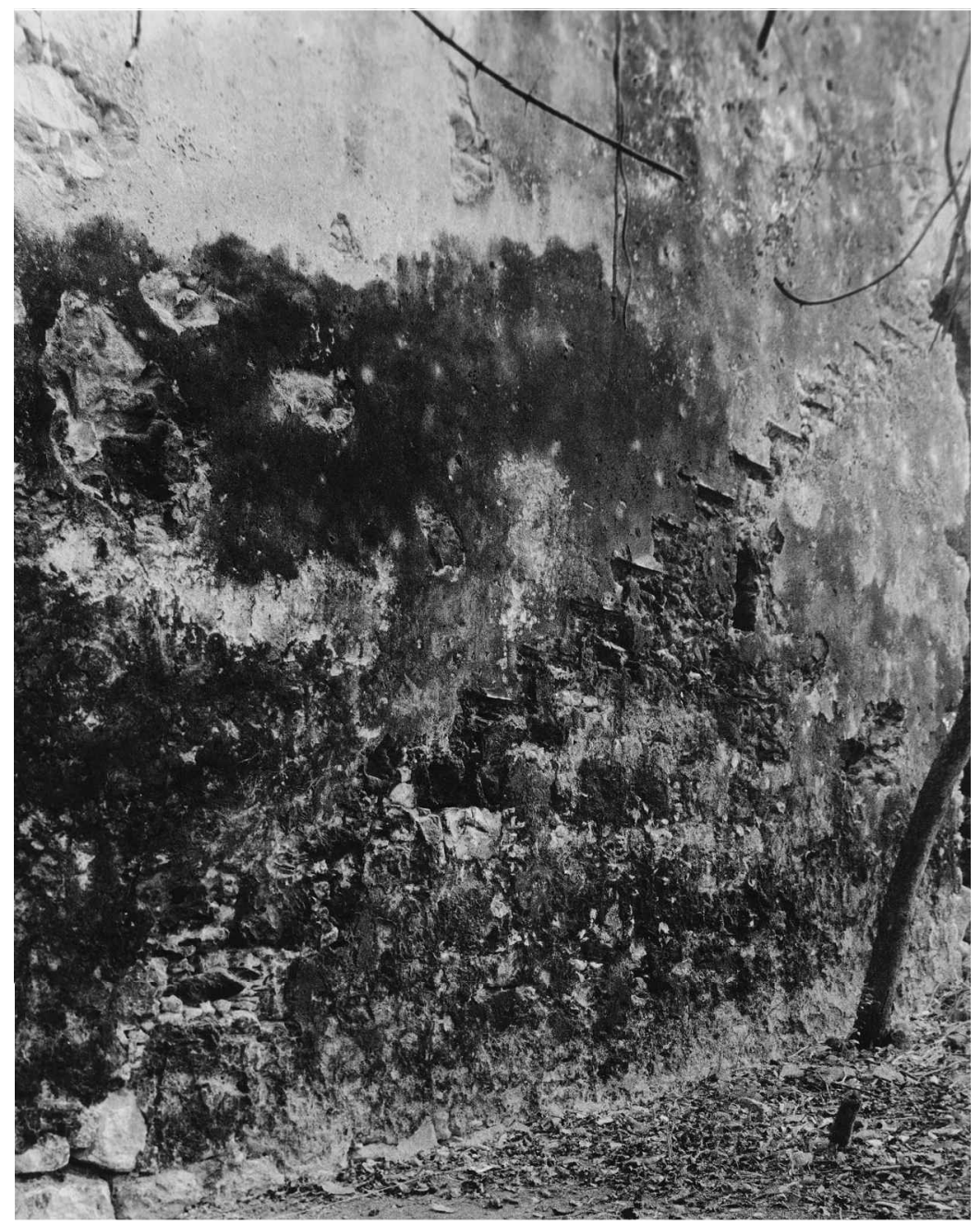

Plate 2 Traces of a stairway on the southern exterior wall of slaveholder's house.

when sugar prices were soaring. Moreno Fraginals suggests that slave raiding from coffee plantations became the solution to this problem, and he identifies slave raiders as displaced white peasants who became rancheadores - pursuers of slave runaways. In addition to pursuing runaways, these slave catchers organized gangs and stole black laborers from one plantation and would sell them to another plantation (Moreno Fraginals 1976: 133, 138). Planters were wary of rancheadores because they could never be certain that if a runaway was captured that he or she would be returned to the original owner. Although regulations were instituted for the proper capture and return of slave runaways, a walled slave village could serve as a deterrent to all slave raiders, whether they were maroons or rancheadores. 


\section{Slave resistance on Cuban plantations}

In Cuba, as elsewhere in the Americas, enslaved men and women were engaged in many different forms of resistance, including revolts, homicides, suicides, maroonage as well as covert and cultural resistance (see Barcia Paz 1998). The barracones and the walled slave villages were obviously built to prevent slave revolts and runaways, two of the most overt forms of resistance that carried the most severe punishment. Yet, despite the potential consequences, both running away and revolts were significantly high on Cuban plantations. In Matanzas province alone 399 acts of violence, including attempted revolts, were reported from 1825 to 1850 (Paquette 1988: 72).

The most overt form of resistance identified thus far at the property of Ignacio O'Farrill occurred at the sugar plantation of San Juan de Nepomuceno, which was close to the cafetal Santa Ana de Viajaca. In 1841, forty-five enslaved workers ran far away to an 'inaccessible distance in the sierras' (ANC GSC 1841). They apparently fled the plantation because of the poor treatment they received from a new plantation manager. All but eight of the enslaved workers returned to the plantation. A party of armed men with dogs, undoubtedly rancheadores, captured some of them, while the others surrendered themselves to the authorities.

Certainly covert acts of resistance, such as feigning illness or misplacing tools, were certainly more commonplace than overt resistance. Covert acts of resistance also had the advantage of taking place, yet going undetected by slaveholders and managers. The archaeological study of slave villages is most capable of uncovering evidence of covert, everyday resistance. In the archaeological study of plantation space, this form of resistance is most evident in modifications enslaved people made to their houses or yard areas. On many southern plantations in the United States, enslaved people dug underground storage pits beneath the floorboards of their houses to store food and other valuables. Slaveholders tried to stop this activity in various ways, for example, by raising the houses on building piers, but enslaved people continued to dig the pits despite slaveholders' prohibitions (Singleton 1998: 179-80). In Jamaica, enslaved people challenged the imposed European norms for the spatial arrangement of their villages by developing their own inside-outside house-yard activity that had its origins in Africa, but was adapted to the Jamaican environment (Armstrong 1999: 178; Armstrong and Kelly 2000).

Written sources on Cuban slavery suggest that enslaved people also modified their living spaces. In the previously mentioned essay by Ávaro Reynoso, one example he gives to illustrate the inefficiency of the barracones was that 'in their rooms the blacks establish divisions and subdivisions, construct lofts or granaries to store their harvests; additionally, they often cook in their rooms without building appropriate stoves for preventing fire' (Reynoso 1861: 328, my translation). Other historical sources indicate that, contrary to the planters' dictate of separating the living areas of male and female slaves, entire slave families lived within the one-room cells of the barracón (Scott 1985: 19-20). Even in prison-like quarters of the barracones, enslaved people found ways to alter their living arrangements.

Archaeological testing at the slave village of El Padre has not been sufficient to date to identify suggestions of slave-induced modifications either to the excavated structure or to the yard area. Many of the recovered artifacts, however, offer insights into the ways in 
which enslaved people fashioned their quarters, and, at least one artefact - a ceramic disc - can potentially be considered within the realm of cultural resistance. In general, the artefacts recovered from the El Padre slave quarter are similar to and, in some cases, identical to the kinds of artefacts recovered from slave quarters both in the United States and on other Caribbean islands. British refined earthenwares, primarily pearl-wares and white-wares, are the predominate tablewares. Similarly, as is the case at other slave sites, less expensive undecorated or minimally decorated wares (e.g. shell-edged ceramics) occur in higher quantities than the more expensive, decorated wares. Of the decorated wares, annular/mocha wares are more common than either hand-painted or transfer-print ceramics. Curiously, more transfer-print ceramics - the most expensive of the English wares - were recovered than mayólicas, tin-enameled wares made in either Spain or Latin America. The English wares may have been preferred, because they were more durable and sometimes cost less than mayólica (Arrazcaeta et al. 1999: 45). The only mayólica identified thus far is Triana policromo, a ware made in Seville, Spain.

The major difference in the ceramic inventory at El Padre from other slave sites in the Americas is that all the coarse earthenwares used for cooking and storage are of Hispanic origins in both manufacture and in vessel shapes. These coarse earthenwares are of varying sizes and shapes, some glazed and others unglazed. No slave-made pottery comparable to either colonowares (Ferguson 1992) or Afro-Caribbean wares (e.g. Armstrong 1999; Peterson et al. 1999) has been identified at El Padre or any other historic site in Western Cuba. The only hand-built earthenwares recovered archaeologically are associated with the former aboriginal populations (see Domínguez 1984, pers. comm. 1999). In addition to ceramics, other artefacts recovered include bone buttons, glass beads, iron-kettle fragments and stub-stem pipes of Spanish manufacture.

All the recovered artefacts suggest that enslaved people on Cuban plantations, like other enslaved peoples elsewhere in the Americas, acquired these objects through purchase or trade, and therefore represent, to some extent, their personal tastes in selfpresentation. That these household objects were acquired through purchase rather than issued as provisions is supported from Abbot's observations at Angerona:

It is the maxim with the proprietor that negroes should have money and spend it. To encourage the latter part of this plan, he furnishes a shop in an apartment of the building next to the mill, with everything they wish to buy that is proper for them; cloth cheap and showy; garments gay and warm; crockery; beads; crosses; guano, or the American palm, that they make neat hats for themselves; little cooking pots, \& \&. He puts everything at low prices; and no peddler is permitted to show his wares on the estate.

(Abbot 1829: 141)

The plantation shop at Angerona may have had a unique situation at the time of Abbot's visit, but, in later decades, plantation shops were common on large Cuban sugar estates (Scott 1985: 184-6). The reference to peddlers not being allowed on the estate, however, suggests that enslaved people regularly traded with such peddlers during the heyday of coffee plantations. Enslaved people could exercise some choice in the objects they acquired for themselves, but the selection made available to them was limited, and, perhaps, influenced by stereotyped notions of their tastes, as suggested in Abott's remarks. 
A ceramic disk measuring $2 \mathrm{~cm}$ in diameter and made of English blue-on-white transfer print is the one artefact that could be considered an example of cultural resistance. Cultural resistance is used here to refer to shared practices that served to critique the power of the dominant as well as to create a world removed from the oppression of everyday life (Scott 1990; e.g. Singleton 1998; Thomas 1998 on slave resistance and archaeology). On Cuban plantations, cultural resistance was manifested in various ways, including song, dance, folktales, religion and medicinal practices (Barcia Paz 1998: 23-8). The ceramic disk was most likely made from a broken fragment of ceramic that was reworked by smoothing the edges into a rounded form. Similar artefacts have been recovered from slave sites in the southern United States (e.g. Russell 1997: 75) and in the Caribbean (Armstrong 1990b: 137-8; Pulsipher and Goodwin 1999: 30). On the island of Montserrat, modern Montserratians describe a game they call 'Chiney Money' in which these ceramic disks are used. In the game, three ceramic pieces are thrown on a table, and the arrangement in which the pieces fall determines the thrower's score (Pulsipher and Goodwin 1999: 30, n. 57). Another game, using cowrie shells, known as 'Paw Paw', played by Afro-New Englanders in the eighteenth century, also involved throwing gaming pieces (cowrie shells) and the position in which the pieces landed determined the thrower's score (Pierson 1988: 102). Both of these games were possibly derived from African divination practices. A key principle of African divination involves throwing objects (e.g. beads, cowries, seeds, etc.) and using the arrangement in which the pieces land either to predict the future or to determine a course of action for the person seeking advice from the diviner. Given the importance of divination in the Afro-Cuban religion Santería, it should not be surprising to find artefacts suggestive of divining and of other African religious practices from a Cuban slave quarter. Religious paraphernalia has increasingly been found at sites occupied by people of African descent in the Americas (e.g. Brown and Cooper 1990; Ferguson 1999; Wilkie 1997). Throughout the Americas, enslaved people relied upon religion as a source of empowerment against their day-to-day oppression.

\section{Summary and conclusion}

Plantation slavery came late to Cuba compared to its English and French Caribbean neighbors, but the island became the center for the slave trade and plantation slavery in the nineteenth-century Caribbean. In an effort to curb the rebellious activities of a growing slave population, slaveholders adopted management practices that resembled prison life. This jail-like character was particularly evident in the built environment of slave quarters and the spatial order of plantations. While the barracones and the walled slave villages served as deterrents to overt forms of slave resistance, they were not completely effective. Enslaved men and women still ran away, planned rebellions, took their owners' lives as well as their own lives. Through various forms of everyday and cultural resistance, enslaved people covertly challenged grueling work routines and inhuman living conditions.

Slaveholders, like Reynoso, recognized the failure of the prison-like approach to slavery, and urged a more paternalistic approach comparable to that advocated by proslavery reformers in the southern United States. Reynoso's writings were similar in scope to those of the southern reformists who championed notions of 'ideal' treatment for 
enslaved laborers, but, in reality, the conditions of most enslaved people remained unchanged (Singleton 1988: 354-5; Chappell 1999: 242-3). All slaveholders desired hardworking, loyal, well-behaved enslaved laborers. Reformists reasoned that this goal could best be achieved through improvements in housing, food or health care. What slaveholders failed to recognize was that enslaved laborers had their own notions of an ideal existence. They did not want to be enslaved under any circumstances. Consequently, they sought various ways to undermine slaveholder authority.

\section{Acknowledgements}

I am very grateful to Dr Eusebio Leal Spengler, historian for the City of Havana, for providing with me the opportunity to conduct this research through the Archaeology Department, Office of the Historian for the City of Havana, Cuba. I thank the following persons for their assistance and generosity in making this research possible: Roger Arrazacaeta Delgado, Dr Lourdes Domínguez, Carlos Alberto Hernández Oliva, Lisette Roura Alvarez, Karen Mahé Lugo Romera, Sonia Menéndez Castro, Anicia Hernández Gonzáles, Dania Hernández Perdices, Beatrriz Antonia Rodríguez Basulto, Francis Séra Alvarez, Ivalú Rodríguez Gil, Antonio Qúevedo Herrero, Aldo Primiano Rodríguez, Néstor Martí Delgado, Juan Carlos Méndez Hernández, Adrián Labrada Milán, Alejandro Ramírez Anderson, Jorge Luis García Báez, Jorge Ponce Aguilar, Ramon Artiles Avela, Carlos Suárez Sardiña, Manuel Barcia Paz, Leida Fernandez Prieto, Dr Gabino la Rosa Corzo, Marta Z. Troncoso Hernández, Ismael Pérez Pérez, Consuelo Bueno Pérez, Mark Hauser, Stephan Lenik and Miguel Herrera.

This paper has also benefited from comments I received from presentations I gave at the Material Culture/Visual Culture Working Group at the University of Maryland and the Department of Anthropology Seminar Series, Syracuse University. I am indebted to Paul Shackel for his suggestions. I am totally responsible for any errors or shortcomings. The field research at El Padre was undertaken during my tenure at the Smithsonian Institution through a Scholarly Studies Grant, Office of Fellowships and Grants, Smithsonian Institution, Washington, DC.

Department of Anthropology Syracuse University

\section{References}

Abbot, Abiel. 1829. Letters Written in the Interior of Cuba. Boston, MA: Bowles \& Dearborn. Archivo Nacional de Cuba (ANC). Archivo: de Cortés (AC), Fondo: Escibanía (E) 1849-53, Legajo: 227, No. de orden: 7.

ANC Fondo: Escribanía Mayor de Real Hacienda (EMRH), 1834 Legajo: 142, No 2662. Testamentaria del Presbitero D. Ignacio O'Farrill, 18 de Febrero [Father Ignacio O'Farrill's will and last testament, 18 February 1834].

ANC: Fondo: Gobierno Superior Civil (GSC) 1825, Legajo 1469, No 57999. Reglamento de Policia Rural de la Jurisdiccion del Gobierno de Matanzas, Octubre 22 de 1825.

ANC: Fondo: GSC 1841, Legajo 617, No. de Orden 19712. 


\section{Theresa A. Singleton}

ANC: Fondo: Gobierno General 1878, Legajo: 32, Expediente 1283

ANC: Fondo: Protocolo de Salinas 1829. Imposición de Ignacio O’Farrill a Don Nicholás Manuel de Escovedo y Rivero [Imposition of Ignacio O'Farrill to Nicholás Manuel de Escovedo y Rivero].

Armstrong, D. 1990a. The Afro-Jamaican house-yard: an archaeological and ethnohistorical perspective. Florida Journal of Anthropology, Special Publication, 5: 51-63.

Armstrong, D. 1990b The Old Village and the Great House: An Archaeological and Historical Examination of Drax Hall Plantation, St. Anne's Bay, Jamaica. Urbana: University of Illinois Press.

Armstrong, D. 1999. Archaeology and ethnohistory of the Caribbean plantation. In I, Too, Am America: Archaeological Studies of African-American Life (ed. T. A. Singleton). Charlottesville: University Press of Virginia, pp. 173-92.

Armstrong, D. and Kelly, K. 2000. Settlement patterns and the origins of African Jamaican society: Seville Plantation, St. Ann's Bay, Jamaica. Ethnohistory, 47(2):369-97.

Arrazcaeta, R., Quevedo, A., Rodríguez, I. and Cueto, T. 1999. Cerámica Inglesa en la Habana colonial. Opus Habana, 3(3-4): 45-9.

Barcia Paz, M. 1998. La Resistencia Esclava en Las Plantaciones Cubanas, 1790-1870: Pinar del Rio, Cuba: Vitral.

Bergad, L. W. 1990. Cuban Rural Society in the Nineteenth Century: The Social and Economic History of Monoculture in Matanzas. Princeton, NJ: Princeton University Press.

Bergad, L. W., Iglesias García, F. and Carman Barcia, M. 1995. The Cuban Slave Market 1790-1880. Cambridge: Cambridge University Press.

Bernard Bosch, L., Blanco Conde, V. and Rives Pantoja, A. 1985. La Manuela: Arqueología de un cafetal habanero. Havana: Editorial de Ciencias Sociales.

Brown, K. L. and Cooper, D. 1990. Structural continuity in an African-American slave and tenant community. Historical Archaeology, 24(4): 7-19.

Chappell, E. 1999. Museums and American slavery. In I, Too, Am America: Archaeological Studies of African-American Life (ed. T. A. Singleton). Charlottesville: University Press of Virginia, pp. 240-58.

Delle, James. 1998. An Archaeology of Social Space: Analyzing Coffee Plantations in Jamaica's Blue Mountains. New York: Plenum.

Domínguez, L. 1984. Arqueología colonial cubana dos estudios. Havana: Editorial Ciencias Sociales. Epperson, T. 1990. Race and the disciplines of the plantation. Historical Archaeology, 24(4): 29-36.

Epperson, T. 1999. Constructing difference: the social and spatial order of the Chesapeake Plantation. In I, Too, Am America: Archaeological Studies of African American Life (ed. T. A. Singleton). Charlottesville: University Press of Virginia, pp. 159-72.

Epperson, T. 2000. Panoptic plantations: the garden sights of Thomas Jefferson and George Mason. In The Lines that Divide: Historical Archaeologies of Race, Class, and Gender (ed. J. A. Delle, S. A. Mrozowski and R. Paynter). Knoxville: University of Tennessee Press, pp. 58-77.

Ferguson, L. 1992. Uncommon Ground: Archaeology and Early African America, 1650-1800. Washington, DC: Smithsonian Institution Press.

Ferguson, L. 1999. The cross is a magic sign: marks on eighteenth-century bowls in South Carolina. In I, Too, Am America: Archaeological Studies of African-American Life (ed. T. A. Singleton). Charlottesville: University Press of Virginia, pp. 116-31.

Foucault, M. 1979. Discipline and Punishment: The Birth of the Prison. New York:Vintage Books.

Franco Ferrán, J. L. 1986. Esquema histórico sobre la trata negrera y la esclavitud. In La Esclavitud en Cuba. Havana: Instituto de Ciencias Históricas, Editorial Academia, pp. 1-10. 
González Fernández, D. 1991. La economía cafetalera cubana: 1790-1860. In Las Racies Históricas del Pueblo Cubano, I (eds C. Naranjo Orovio and M. Prig-Samper). Arbor, pp. 547-8, 161-79.

Gordon y Acosta, A. 1896. Una responsabilidad de nuestros cafés. Havana: El Fígaro.

Jopling, C. F. 1988. Puerto Rican Houses in Sociohistorical Perspective. Knoxville: University of Tennessee Press.

La Rosa Corzo, G., and Pérez Padrón, J. 1994. La resistencia eslava en La Sierra del Grillo: estudio arqueológico. In Estudios Arqueológicos Compliación de temas. Havana: Editorial Academia.

Lefebvre, H. 1991.The Production of Space. Oxford: Blackwell.

McKee, L. 1992. The ideals and realities behind the design and use of the 19th-century Virginia slave cabins. In The Art and Mystery of Historical Archaeology: Essays in the Honor of James Deetz (eds A. Yentsch and M. C. Beaudry). Boca Raton, FL: CRC Press, pp. 195-213.

Méndez, M. I.1952. Biografía del cafetal Angerona. On file at the Biblioteca Nacional José Marti, Havana, 24 pp.

Moreno Fraginals, M. 1976. The Sugar Mill: The Socioeconomic Complex of Sugar in Cuba (trans. C. Belfarge). New York: Monthly Review Press.

Moreno Fraginals, M. 1977. Africa in Cuba: a quantitative analysis of the African population in the Island of Cuba. In Comparative Perspectives on Slavery in New World Plantation Societies (eds V. Rubin and A. Tuden). Annals New York Academy of Sciences, 292: 187-201.

Moreno Fraginals, M. 1978. El Ingenio: complejo económico social cubano del azúcar, 3 vols. Havana: Editorial de Ciencias Sociales.

Núñez Jiménez, A. 1959. Geografia de Cuba. Havana: Lex.

Ortiz, F. 1989 [1916]. Los Negros Esclavos. Havana: Editorial de Ciencias Sociales.

Paquette, R. L. 1988. Sugar Is Made with Blood: The Conspiracy of La Escalera and the Conflict between Empires over Slavery in Cuba. Middletown, CT: Wesleyan University Press.

Pérez de la Riva, F. 1944. El Café: Historia de su cultivo y explotacion en Cuba. Havana: Jesús Montrero.

Pérez de la Riva, F. 1952. La habitacion rural en Cuba. Revista de arqueologia y ethologia, Año 7: 295-392.

Pérez de la Riva, J. 1975. El Barracon y otros Ensayos. Havana: Editorial de Ciencias Sociales.

Petersen, J. B., Waters, D. and Nicolson, D. V. 1999. Continuity and syncretism in Afro-Caribbean ceramics from the Northern Lesser Antilles. In African Sites Archaeology in the Caribbean (ed. J. B. Haviser). Princeton, NJ: Markus Wiener, pp. 157-95.

Piersen, W. 1988. Black Yankees: The Development of an Afro-American Subculture in EighteenthCentury New England. Amherst: University of Massachusetts Press.

Rebelledo, A. D. J. 1910. Manual del Construction. Madrid.

Pulsipher, L. M. and Goodwin, C. M. 1999. Here where the old time people be: reconstructing the landscapes of the slavery and post-slavery era in Montserrat, West Indies. In African Sites Archaeology in the Caribbean (ed. J. B. Haviser). Princton, NJ: Markus Wiener, pp. 9-33.

Reynoso, Á. 1861. Estudios Progresivos sobre Varias Materias Científicas, Agrícolas e Industriales: Colección de escritos sobre los cultivos de la caña, café, tabaco, maíz, arroz. Havana: El Tiempo.

Russell, A. E. 1997. Material culture and African-American spirituality at the Hermitage. Historical Archaeology, 31(2): 63-80.

Samson, R. 1992. Knowledge, constraint, and power in inaction: the defenseless medieval wall. Historical Archaeology, 26(3): 26-44. 


\section{Theresa A. Singleton}

Scott, J. C. 1990. Domination and the Arts of Resistance: Hidden Transcripts. New Haven, CT: Yale University Press.

Scott, R. 1985. Slave Emancipation in Cuba: The Transition to Free Labor, 1860-1899. Princeton, NJ: Princeton University Press.

Shields, R. 1999. Lefebvre, Love \& Struggle: Spatial Dialectics. London: Routledge.

Shackel, P. A. 1996. Culture Change and the New Technology: An Archaeology of the Early American Industrial Era. New York: Plenum.

Singleton, T. 1988. An archaeological framework for slavery and emancipation. In The Recovery of Meaning: Historical Archaeology in the Eastern United States (ed. M. P. Leone and P. B. Potter, Jr.). Washington, DC: Smithsonian Institution Press, pp. 345-70.

Singleton, T. 1998. Cultural interaction and African American identity in plantation archaeology. In Studies in Culture Contact: Interaction, Culture Change, and Archaeology (ed. J. G. Cusick). Center for Archaeological Investigations, Occasional Paper No.25. Carbondale: Southern Illinois University, pp. 172-88.

Singleton, T. and Bograd, M. 1995. The archaeology of the African diaspora in the Americas. Guides to the Archaeological Literature of the Immigrant Experience in America, No.2. Tucson, AZ: Society for Historical Archaeology.

Thomas, B. W. 1998. Power and community: the archaeology of slavery at the Hermitage plantation. American Antiquity, 63(4): 531-51.

Trouillot, M.-R. 1993. Coffee planters and coffee slaves in the Antilles: the impact of a secondary crop. In Cultivation and Culture: Labor and the Shaping of Slave Life in the Americans (eds I. Berlin and P. D. Morgan). Charlottesville: University of Virginia Press, pp. 124-37.

Weiss, J. E. 1989. La Arquitectura Colonial Cubana. Havana: Editorial Pueblo y Educacíon.

Wilkie, L. 1997. Secret and sacred: contextualizing the artifacts of African-American magic and religion. Historical Archaeology, 31(4): 81-106. 